\title{
Characterization and source apportionment of atmospheric organic and elemental carbon during fall and winter of 2003 in Xi'an, China
}

\author{
J. J. Cao ${ }^{1}$, F. Wu ${ }^{1,2}$, J. C. Chow ${ }^{3}$, S. C. Lee ${ }^{4}$, Y. Li ${ }^{1}$, S. W. Chen ${ }^{5}$, Z. S. An ${ }^{1}$, K. K. Fung ${ }^{6}$, J. G. Watson ${ }^{3}$, C. S. Zhu ${ }^{1}$, \\ and S. X. Liu ${ }^{1}$ \\ ${ }^{1}$ SKLLQG, Institute of Earth Environment, Chinese Academy of Sciences, Xi' an 710075, China \\ ${ }^{2}$ The Graduate School of Chinese academy of Sciences, Beijing 100049, China \\ ${ }^{3}$ Desert Research Institute, Reno, Nevada, USA \\ ${ }^{4}$ The Hong Kong Polytechnic University, Hong Kong, China \\ ${ }^{5}$ Tongji University, Shanghai 200092, China \\ ${ }^{6}$ Atmoslytic, Inc., Calabasas, CA, USA
}

Received: 14 March 2005 - Published in Atmos. Chem. Phys. Discuss.: 1 June 2005

Revised: 1 September 2005 - Accepted: 9 November 2005 - Published: 22 November 2005

\begin{abstract}
Continuous measurements of atmospheric organic and elemental carbon (OC and EC) were taken during the high-pollution fall and winter seasons at Xi' an, Shaanxi Province, China from September 2003 through February 2004. Battery-powered mini-volume samplers collected $\mathrm{PM}_{2.5}$ samples daily and $\mathrm{PM}_{10}$ samples every third day. Samples were also obtained from the plumes of residential coal combustion, motor-vehicle exhaust, and biomass burning sources. These samples were analyzed for OC/EC by thermal/optical reflectance (TOR) following the Interagency Monitoring of Protected Visual Environments (IMPROVE) protocol. OC and EC levels at Xi' an are higher than most urban cities in Asia. Average $\mathrm{PM}_{2.5}$ OC concentrations in fall and winter were $34.1 \pm 18.0 \mu \mathrm{g} \mathrm{m}^{-3}$ and $61.9 \pm 33.2 \mu \mathrm{g} \mathrm{m}^{-3}$, respectively; while EC concentrations were $11.3 \pm 6.9 \mu \mathrm{g} \mathrm{m}^{-3}$ and $12.3 \pm 5.3 \mu \mathrm{g} \mathrm{m}^{-3}$, respectively. Most of the OC and EC were in the $\mathrm{PM}_{2.5}$ fraction. OC was strongly correlated $(\mathrm{R}>0.95)$ with $\mathrm{EC}$ in the autumn and moderately correlated $(\mathrm{R}=0.81)$ with $\mathrm{EC}$ during winter. Carbonaceous aerosol $(\mathrm{OC} \times 1.6+\mathrm{EC})$ accounted for $48.8 \% \pm 10.1 \%$ of the $\mathrm{PM}_{2.5}$ mass during fall and $45.9 \pm 7.5 \%$ during winter. The average OC/EC ratio was 3.3 in fall and 5.1 in winter, with individual OC/EC ratios nearly always exceeding 2.0. The higher wintertime OC/EC corresponded to increased residential coal combustion for heating. Total carbon (TC) was associated with source contributions using absolute principal component analysis (APCA) with eight thermally-derived carbon fractions. During fall, $73 \%$ of TC was attributed to gasoline engine exhaust, $23 \%$ to diesel exhaust, and $4 \%$ to biomass burning. During winter, $44 \%$ of TC was attributed to gasoline engine exhaust, $44 \%$ to coal
\end{abstract}

Correspondence to: J. J. Cao

(cao@loess.llqg.ac.cn) burning, $9 \%$ to biomass burning, and $3 \%$ to diesel engine exhaust.

\section{Introduction}

This study examines temporal variations of $\mathrm{PM}_{2.5}$ and $\mathrm{PM}_{10}$ concentrations of organic and elemental carbon (OC and EC) in Xi' an, China. ( $\mathrm{PM}_{2.5}$ is particulate matter with an aerodynamic diameter smaller than 2.5 micrograms $[\mu \mathrm{m}], \mathrm{PM}_{10}$ is particulate matter with an aerodynamic diameter smaller than $10 \mu \mathrm{m})$. This study also quantifies contributions of organic and elemental carbon in Xi' an from coal combustion, vehicle exhaust, fugitive dust and dust storms (Cao et al., 2005; Gao et al., 1997; Zhang et al., 1993; Zhuang et al., 1992).

With a population of five million, Xi'an, in Shaanxi Province, is the largest city in northwestern China. It has served as the capital city of 13 Chinese dynasties for more than a millennium. Since the discovery in 1974 of hundreds of buried life-size terra-cotta figures of warriors and horses, the city has been a major tourist attraction. Xi' an also experiences some of the worst air pollution among China's cities (Zhang et al., 2001, 2002), where elevated carbonaceous aerosol components contribute to high PM levels. Several studies have been conducted in China's well-developed coastal cities, such as Beijing, Shanghai, Guangzhou, and Hong Kong (Cao et al., 2003, 2004; He et al., 2001; Louie et al., 2005a, b; Ye et al., 2003), but few measurements are available from inland cities, such as Xi'an.

OC and EC in suspended particulate matter (PM) play important roles in health, visibility, and climate effects (ACEAsia, 1999; Cooke et al., 1999; IPCC, 2001; UNEP and NOAA, 2003; Vedal, 1997; Watson, 2002). EC, which is

(C) 2005 Author(s). This work is licensed under a Creative Commons License. 


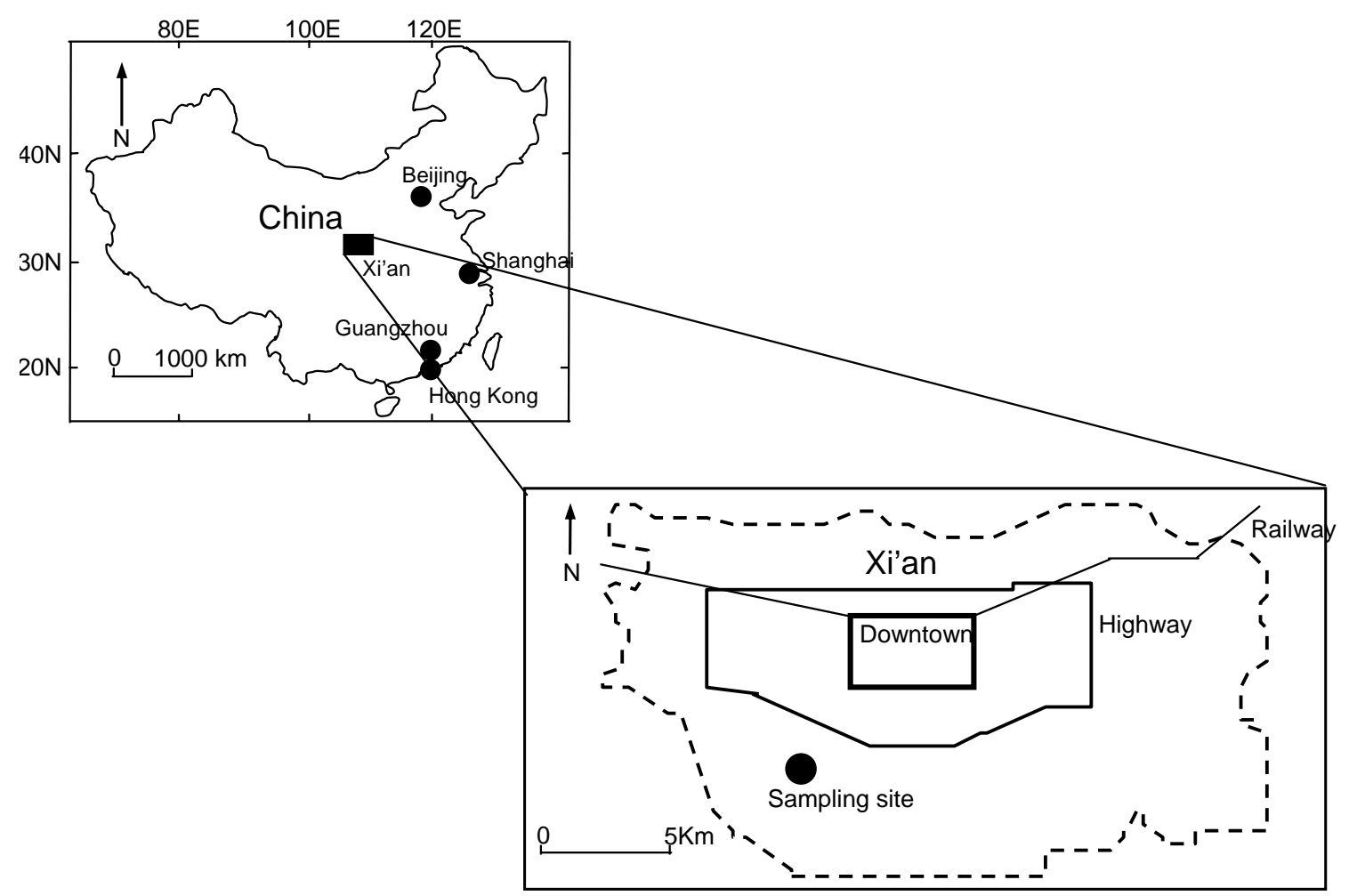

Fig. 1. Location of the sampling site at Xi' an, China.

often equated with optically-derived, light-absorbing black carbon (BC), is known to cause heating in the air on a regional scale, thus altering atmospheric stability and vertical mixing, and affecting large-scale circulation and the hydrologic cycle (Menon et al., 2002). Since about one fourth of global BC emissions are believed to originate from China (Cooke et al., 1999), a reduction of BC emissions in China could produce positive consequences for global warming (Jacobson, 2002).

\section{Sampling and analysis}

\subsection{Sampling site}

Xi' an is located on the Guanzhong Plain at the south edge of the Loess Plateau $400 \mathrm{~m}$ above sea level at $33^{\circ} 29^{\prime}-34^{\circ} 44^{\prime} \mathrm{N}$, $107^{\circ} 40^{\prime}-109^{\circ} 49^{\prime} \mathrm{E}$ (Fig. 1). The monitoring site was located in an urban-scale zone of representation (Chow et al., 2002) surrounded by a residential area $\sim 15 \mathrm{~km}$ south of downtown Xi'an, where there are no major industrial activities, nor local fugitive dust sources. $\mathrm{PM}_{2.5}$ and $\mathrm{PM}_{10}$ samples were obtained from 13 September 2003 to 29 February 2004 from the rooftop of the Chinese Academy of Sciences' Institute of Earth Environment building at $10 \mathrm{~m}$ above ground. Based on local meteorological characteristics and the residential heating season (mid-November through February), the period from 13 September 2003 to 31 October 2003 was designated as fall, and the period from 1 November 2003 to 29 February 2004 was designated as winter.

\subsection{Sample collection}

Daily $\mathrm{PM}_{2.5}$ and every-third-day $\mathrm{PM}_{10}$ samples were collected using two battery-powered mini-volume samplers (Airmetrics, Oregon, USA) operating at flow rates of 5 liters per minute $\left(\mathrm{L} \mathrm{min}^{-1}\right.$; Cao, 2003). Prior to field operations, calibrated MiniVol samplers were collocated with low volume $\mathrm{PM}_{2.5}$ and $\mathrm{PM}_{10}$ Partisol samplers (model 2000, Rupprecht \& Patashnick, Albany, New York, USA) at the Hong Kong Polytechnic University. The difference between the two types of samplers was less than $5 \%$ for the $\mathrm{PM}_{2.5}$ and $\mathrm{PM}_{10}$ mass.

PM samples were collected on $47 \mathrm{~mm}$ Whatman quartz microfiber filters $(\mathrm{QM} / \mathrm{A})$ that were pre-heated at $900^{\circ} \mathrm{C}$ for three hours before sampling. The exposed filters were stored in a refrigerator at $\sim 4^{\circ} \mathrm{C}$ before chemical analysis to minimize the evaporation of volatile components. Quartz-fiber filters were analyzed gravimetrically for mass concentrations using a Sartorius MC5 electronic microbalance with a $\pm 1 \mu \mathrm{g}$ sensitivity (Sartorius, Göttingen, Germany) after 24-h equilibration at a temperature between $20^{\circ} \mathrm{C}$ and $23^{\circ} \mathrm{C}$ and a relative humidity $(R H)$ between $35 \%$ and $45 \%$. Each filter was weighed at least three times before and after sampling, and the net mass was obtained by subtracting the 
Table 1. Average of OC and EC concentrations during September 2003 to February 2004 at Xi' an, China.

\begin{tabular}{|c|c|c|c|c|c|c|c|c|c|}
\hline \multirow{2}{*}{ Season } & \multirow{2}{*}{ Month } & \multicolumn{2}{|c|}{ Sample numbers } & \multicolumn{2}{|c|}{$\mathrm{OC}^{\mathrm{a}}$} & \multicolumn{2}{|c|}{$\mathrm{EC}$} & \multicolumn{2}{|c|}{ OC/EC } \\
\hline & & $\mathrm{PM}_{2.5}$ & $\mathrm{PM}_{10}$ & $\mathrm{PM}_{2.5}$ & $\mathrm{PM}_{10}$ & $\mathrm{PM}_{2.5}$ & $\mathrm{PM}_{10}$ & $\mathrm{PM}_{2.5}$ & $\mathrm{PM}_{10}$ \\
\hline \multirow{3}{*}{ Fall } & September & 18 & 6 & $24.9 \pm 10.3^{b}$ & $29.6 \pm 11.2$ & $8.3 \pm 4.5$ & $11.0 \pm 6.4$ & 3.3 & 3.0 \\
\hline & October & 31 & 11 & $39.4 \pm 19.4$ & $50.7 \pm 30.6$ & $13.1 \pm 7.5$ & $17.2 \pm 12.2$ & 3.4 & 3.3 \\
\hline & Average & & & $34.1 \pm 18.0$ & $43.2 \pm 27.1$ & $11.3 \pm 6.9$ & $15.0 \pm 10.7$ & 3.3 & 3.2 \\
\hline \multirow{5}{*}{ Winter } & November & 27 & 8 & $52.4 \pm 27.1$ & $67.5 \pm 25.7$ & $12.1 \pm 5.1$ & $19.8 \pm 8.2$ & 4.3 & 3.6 \\
\hline & December & 29 & 8 & $81.7 \pm 36.2$ & $124.8 \pm 54.8$ & $15.2 \pm 4.6$ & $28.9 \pm 8.9$ & 5.3 & 4.3 \\
\hline & January & 31 & 11 & $63.9 \pm 36.0$ & $80.3 \pm 42.4$ & $10.1 \pm 5.8$ & $16.1 \pm 8.8$ & 6.4 & 5.1 \\
\hline & February & 29 & 9 & $48.6 \pm 21.7$ & $98.7 \pm 87.6$ & $12.0 \pm 4.4$ & $26.8 \pm 18.2$ & 4.1 & 3.5 \\
\hline & Average & & & $61.9 \pm 33.2$ & $93.0 \pm 58.4$ & $12.3 \pm 5.3$ & $22.7 \pm 12.3$ & 5.1 & 4.2 \\
\hline
\end{tabular}

a unit is $\mu \mathrm{g} \mathrm{m}^{-3}$

$\mathrm{b}$ values represent average \pm standard deviation

average of pre-sampling weights from the average of postsampling weights. Differences among replicate weighings were $<10 \mu \mathrm{g}$ for blanks and $<20 \mu \mathrm{g}$ for samples. Sixteen field blanks were collected to correct for adsorbed gas-phase organic components. Volatilization of particle-phase organics during and immediately after sampling was not quantified. A total of $165 \mathrm{PM}_{2.5}$ and $53 \mathrm{PM}_{10}$ samples were collected during the ambient sampling period. Five $\mathrm{PM}_{2.5}$ source samples were collected from residential stoves burning coal, six from alongside a major highway with heavy traffic, and five from smoke plumes when maize residue was burned after harvest.

Meteorological data were monitored continuously with a HFY-IA Wind Speed/Wind Direction Instrument (Changchun Institute of Metrological Instruments, Changchun, Jilin Province, China).

\subsection{Thermal/optical carbon analysis}

A $0.5 \mathrm{~cm}^{2}$ punch from each samples was analyzed for OC and EC with a Desert Research Institute (DRI) Model 2001 Thermal/Optical Carbon Analyzer (Atmoslytic Inc., Calabasas, CA, USA) for eight carbon fractions following the IMPROVE (Interagency Monitoring of Protected Visual Environments) thermal/optical reflectance (TOR) protocol (Chow et al., 1993, 2001, 2004a, 2005; Fung et al., 2002). This produces four OC fractions (OC1, OC2, OC3, and OC4 at $120^{\circ} \mathrm{C}, 250^{\circ} \mathrm{C}, 450^{\circ} \mathrm{C}$, and $550^{\circ} \mathrm{C}$, respectively, in a He atmosphere); a pyrolyzed carbon fraction (OP, determined when a reflected laser light attained its original intensity after $\mathrm{O}_{2}$ was added to the analysis atmosphere); and three EC fractions $\left(\mathrm{EC} 1, \mathrm{EC} 2\right.$, and $\mathrm{EC} 3$ at $550^{\circ} \mathrm{C}, 700^{\circ} \mathrm{C}$, and $800^{\circ} \mathrm{C}$, respectively, in a $2 \% \mathrm{O}_{2} / 98 \% \mathrm{He}$ atmosphere). IMPROVE $\mathrm{OC}$ is defined as $\mathrm{OC} 1+\mathrm{OC} 2+\mathrm{OC} 3+\mathrm{OC} 4+\mathrm{OP}$ and $\mathrm{EC}$ is defined as $\mathrm{EC} 1+\mathrm{EC} 2+\mathrm{EC} 3-\mathrm{OP}$. Inter-laboratory comparisons of samples between IMPROVE protocol with the DRI Model 2001 instrument and the TMO (thermal manganese diox- ide oxidation) method (done by AtmAA, Inc., Calabasas, CA) has shown a difference of $<5 \%$ for total carbon (TC) and $10 \%$ for OC/EC (Fung et al., 2002). Comparisons with other OC/EC methods (Watson et al., 2005) show that IMPROVE_TOR OC and EC are near the middle of the distribution of differences for the average of all methods. Average field blanks were 1.56 and $0.42 \mu \mathrm{g} \mathrm{m}^{-3}$ for $\mathrm{OC}$ and $\mathrm{EC}$, respectively. Quality Assurance/Quality Control (QA/QC) procedures have been described in Cao et al. (2003).

\section{Results and discussion}

\subsection{Temporal variations of OC and EC}

Monthly and seasonally averaged OC/EC concentrations are summarized in Table 1. $\mathrm{PM}_{2.5} \mathrm{OC}$ and EC during winter were 1.8 and 1.1 times, respectively, of those during fall; while. $\mathrm{PM}_{10} \mathrm{OC}$ and $\mathrm{EC}$ during winter were 2.2 and 1.5 times, respectively, of those during fall. Monthly average $\mathrm{OC}$ and EC were highest during December and lowest during September. In December, OC in $\mathrm{PM}_{2.5}$ and $\mathrm{PM}_{10}$ were $81.7 \pm 36.2 \mu \mathrm{g} \mathrm{m}^{-3}$ and $124.8 \pm 54.8 \mu \mathrm{g} \mathrm{m}^{-3}$, respectively; and $\mathrm{EC}$ in $\mathrm{PM}_{2.5}$ and $\mathrm{PM}_{10}$ were $15.2 \pm 4.6 \mu \mathrm{g} \mathrm{m}^{-3}$ and $28.9 \pm 8.9 \mu \mathrm{g} \mathrm{m}^{-3}$, respectively. The maximum-to-minimum ratios for $\mathrm{PM}_{2.5}$ and $\mathrm{PM}_{10}$, were 3.3 and 4.2 for $\mathrm{OC}$ and 1.8 and 2.6 for EC, respectively. Higher variability for OC concentrations may be due to the contributions of different emission sources.

Figure 2 shows that temporal variations of $\mathrm{PM}_{2.5}$ OC coincided with mass and, to a lesser extent, with EC. OC was highly correlated with $\mathrm{PM}_{2.5}$ ( $\mathrm{r}=0.96$, significance level $99 \%)$ and $\mathrm{EC}$ was moderately correlated with $\mathrm{PM}_{2.5}(\mathrm{r}=0.72$, significance level 99\%). $\mathrm{PM}_{2.5}$ OC increased gradually from September to November, and reached a maximum on 14 December $2003\left(189.6 \mu \mathrm{g} \mathrm{m}^{-3}\right)$. Major emission sources of OC and EC in China include coal combustion (mostly 


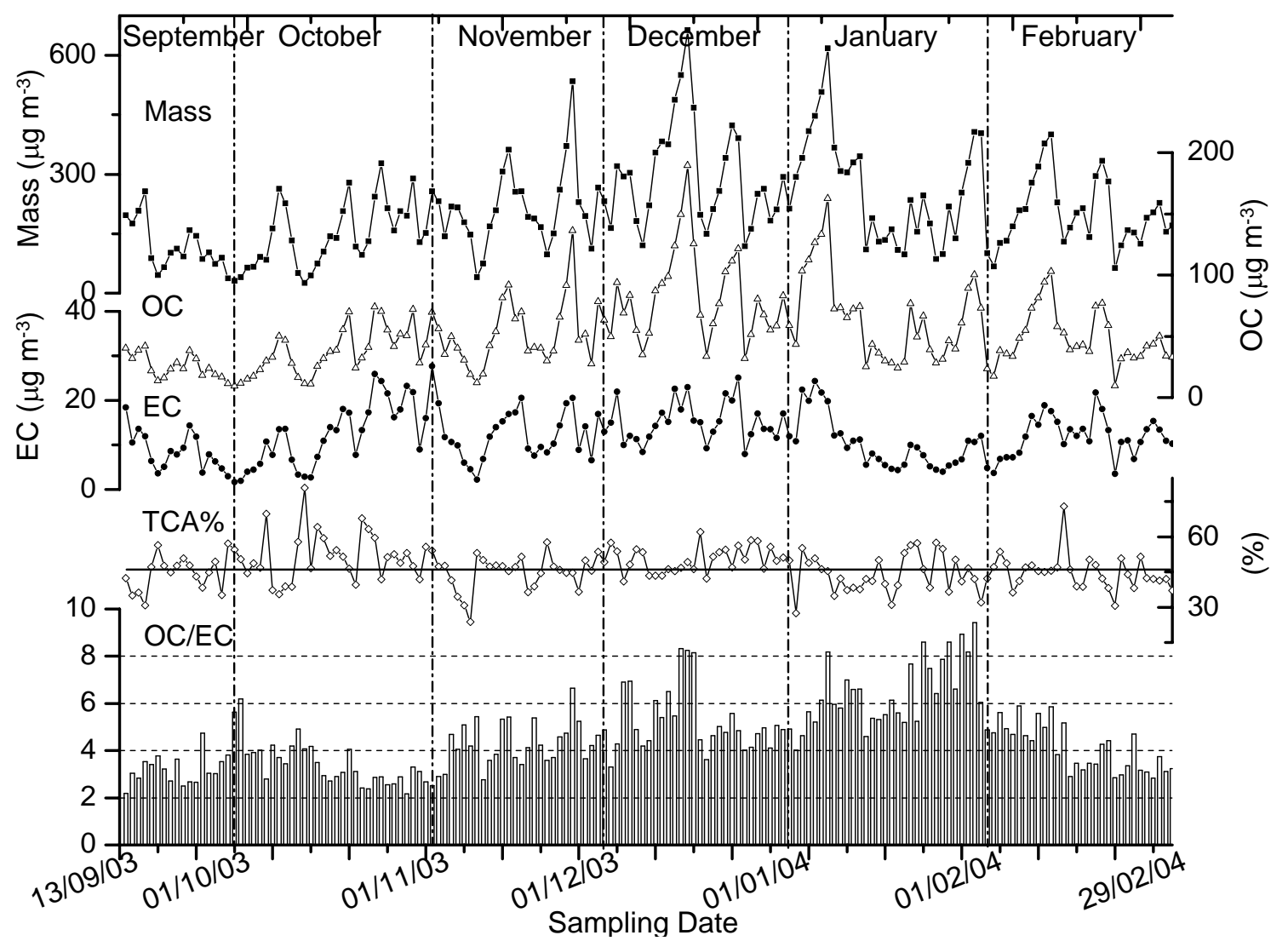

Fig. 2. Time series of $\mathrm{PM}_{2.5}$ mass, organic carbon (OC), elemental carbon (EC), fraction of $\mathrm{PM}_{2.5}$ composed of $\mathrm{OC} \times 1.6+\mathrm{EC}$ (TCA\%), and OC/EC ratios at Xi' an from 13 September 2003 to 29 February 2004. OC is multiplied by 1.6 for the TCA\% calculation to account for unmeasured hydrogen and oxygen in organic material (Turpin and Lim, 2001).

residential), motor-vehicle exhaust, and biomass burning (Streets et al., 2001; Zhang et al., 2001), all of which are also evident in Xi' an. During the fall harvest season in midOctober, the residues of diverse crops like corn and rice are burned. Biofuels are also used by farmers for residential heating and cooking for both fall and winter. Zhang et al. (2001) showed that total suspended particle (TSP) in $\mathrm{Xi}$ 'an reaches maximum levels in winter and minimum levels in summer. After the Chinese Spring Festival (22 January 2004 to 29 January 2004), OC decreases rapidly initially, then decreases further as February progresses. A similar trend was found for EC, but while EC concentration was lowest during the festival, it fluctuated at low values from 22 January 2004 to 5 February 2004.

\subsection{Relationship between OC and EC}

OC/EC ratios give some indication of the origins of carbonaceous $\mathrm{PM}_{2.5}$ (Chow et al., 1996; Gray et al., 1986; Turpin and Huntzicker, 1991). As shown in Fig. 3, strong OC/EC correlations (0.95-0.97) in fall suggest impacts from a combination of common source contributions (i.e. residential and commercial coal combustion, biomass burning, motor- vehicle exhaust). OC/EC correlations (0.81) were lower in winter, consistent with a changing mixture of source contributions. Residential coal combustion was estimated to contribute more than 50\% of TSP in 1997 (Zhang, 2001). Even though many residents in Xi' an have replaced coal with natural gas, a large number of low-income families still use coal for cooking and heating. Coal-fired boilers have been banned within the second beltway in downtown Xi' an since 1998, but due to the low cost of coal, many middle- and small-scale boilers are still in use.

The slopes of OC versus EC in winter were 5.12 for $\mathrm{PM}_{2.5}$ and 3.83 for $\mathrm{PM}_{10}$, compared to those in fall (2.46) (Fig. 3), implying that $\mathrm{OC}$ emissions in winter increased relative to $\mathrm{EC}$ emissions. The difference may be ascribed to the change of emission sources between the two seasons, primarily due to the completion of burning in corn and rice fields.

\subsection{Variability of OC/EC ratios}

OC/EC ratios are influenced by: 1) emission sources; 2) secondary organic aerosol (SOA) formation; and 3) different OC/EC removal rates by deposition (Cachier et al., 1996). Atmospheric EC is directly emitted, while OC can be both 


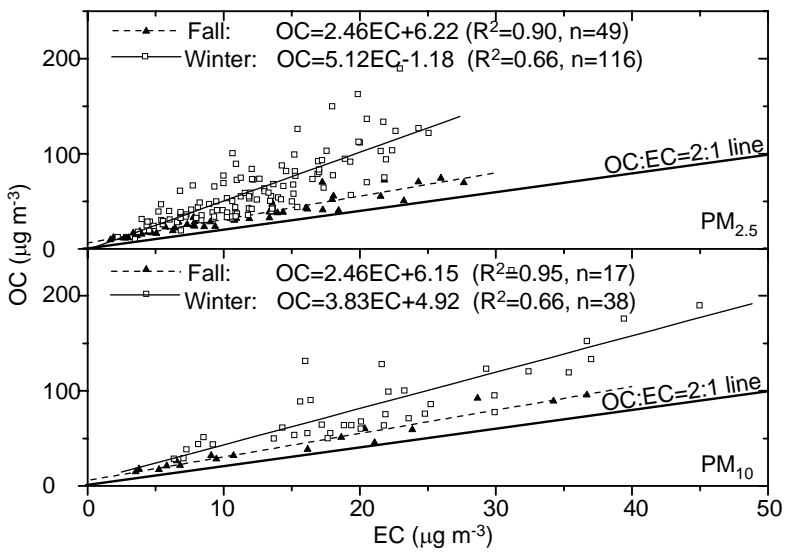

Fig. 3. Relationships between $\mathrm{OC}$ and $\mathrm{EC}$ concentrations in $\mathrm{PM}_{2.5}$ and $\mathrm{PM}_{10}$.

directly emitted and formed in the atmosphere from the low vapor pressure products of chemical reactions involving emissions of volatile organic compounds (VOCs).

As shown in Table 1, monthly averaged OC/EC ratios in $\mathrm{PM}_{2.5}$ and $\mathrm{PM}_{10}$ ranged from 3.0 to 3.4 in fall, and 3.6 to 6.4 in winter. The highest ratios were recorded in January, with 6.4 in $\mathrm{PM}_{2.5}$ and 5.1 in $\mathrm{PM}_{10}$. Daily variations of $\mathrm{PM}_{2.5}$ OC/EC ratios in Fig. 2 show lower ratios and variability in fall and higher ratios and variability in winter.

Regarding source samples, the average OC/EC ratio was 12.0 for coal-combustion, 4.1 for vehicle exhaust, and 60.3 for biomass burning. These ratios are much higher than reported values elsewhere of 2.7 for coal-combustion and 1.1 for motor vehicles (Watson et al., 2001), and 9.0 for biomass burning (Cachier et al., 1989). The individual OC/EC ratios for this study exceeded 2.0 for both $\mathrm{PM}_{2.5}$ and $\mathrm{PM}_{10}$ fractions (Fig. 2), which might reflect the combined contributions from coal combustion, motor-vehicle exhaust, and biomass burning sources. Elevated OC/EC ratios (8.0) during mid-December can be attributed to biomass burning and coal combustion. High OC/EC ratios (6.0-9.0) during the Chinese Spring Festival may be due to lower contributions from motor-vehicle exhaust and biomass burning during the holiday, and higher contributions from residential coal combustion.

\subsection{Contributions to $\mathrm{PM}_{2.5}$ and $\mathrm{PM}_{10}$ mass}

Figure 4 shows a larger $\mathrm{PM}_{10}$ scatter than $\mathrm{PM}_{2.5}$ in both seasons. Daily $\mathrm{PM}_{10}$ in winter varied by a factor of 5.7, ranging from $155 \mu \mathrm{g} \mathrm{m}^{-3}$ (06 November 2003) to $885 \mu \mathrm{g} \mathrm{m}^{-3}$ (14 December 2003), and averaging $450.6 \mu \mathrm{g} \mathrm{m}^{-3}$. The average for fall was $261.9 \mu \mathrm{g} \mathrm{m}^{-3}$. The $\mathrm{PM}_{2.5}$ average was $140.1 \mu \mathrm{g} \mathrm{m}^{-3}$ in fall and $258.7 \mu \mathrm{g} \mathrm{m}^{-3}$ in winter. $\mathrm{PM}_{2.5}$ accounted for $55.6 \%$ of the $\mathrm{PM}_{10}$ in fall, ranging between $44.3 \%$ and $77.4 \%$. In winter, $\mathrm{PM}_{2.5}$ accounted for $60.4 \%$ of the $\mathrm{PM}_{10}$, with a wide range from $33.0 \%$ and $97.6 \%$.

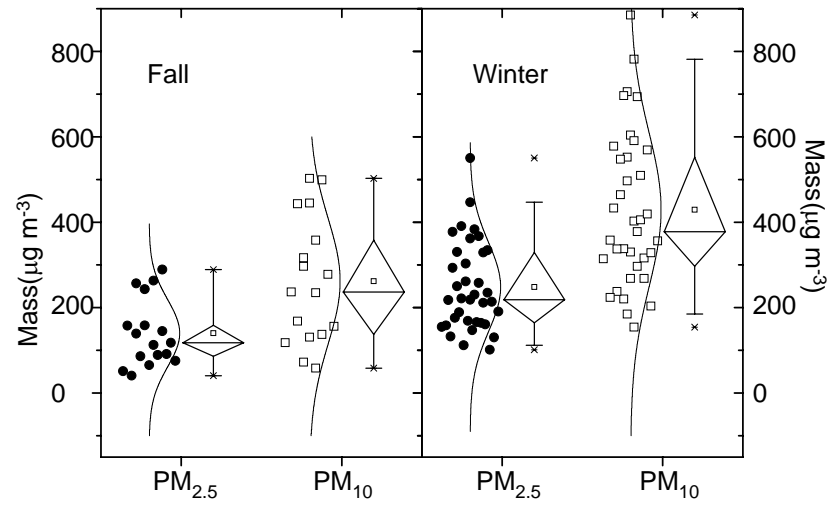

Fig. 4. Distribution of $\mathrm{PM}_{2.5}$ and $\mathrm{PM}_{10}$ mass concentrations during fall and winter. The valid paired samples were 17 in fall and 36 in winter. The box plots indicate the mean 24-h concentration and the min, 1st, 25th, 50th, 75th, 99th and max percentiles. A normal curve is fitted to the measurements.

Compare to Xi'an, the percentage of $\mathrm{PM}_{2.5}$ in $\mathrm{PM}_{10}$ in other Chinese cities was: Shenzhen in $2001-73.3 \%$ (Cao et al., 2003); Zhuhai, $2001-70.8 \%$ (Cao et al., 2003); Chongqing, 1997 - 65.1\% (Wei et al., 1999); Wuhan, 1997 - 60.5\% (Wei et al., 1999); Xi' an, 2003 - 60.4\%; Lanzhou, $1997-51.9 \%$ (Wei et al., 1999). In Xi' an, only five of the $17 \mathrm{PM}_{10}$ sampling days in fall and none of the 36 sampling days in winter were in compliance with China's legislated Class $2 \mathrm{PM}_{10}$ standard of $150 \mu \mathrm{g} \mathrm{m}^{-3}$ (GB 3905-1996). The data depict extreme PM pollution in Xi' an despite the current substantial local government pollution control efforts.

As shown in Table 2, total carbonaceous aerosol (TCA $=\mathrm{OC} \times 1.6+\mathrm{EC}$ ) contributed $48.8 \%$ of $\mathrm{PM}_{2.5}$ in fall and $45.9 \%$ in winter. The percentage of TCA in $\mathrm{PM}_{10}$ was lower than in $\mathrm{PM}_{2.5}$, with an average of $34.5 \%$ in fall and $37.0 \%$ in winter. This may be due to higher contributions of geological matter in coarse particles. The material balance also confirmed that TCA is the dominant component of $\mathrm{PM}_{2.5}(\mathrm{Li}$, 2004). As shown in the time series in Fig. 2, TCA\% varied around the $45 \%$ level during the study and did not correlate with changes of $\mathrm{PM}_{2.5}$ mass or OC/EC concentrations.

$\mathrm{PM}_{2.5}$ OC accounted for $81.8 \%$ and $72.8 \%$ of $\mathrm{PM}_{10}$ OC during fall and winter, respectively, whereas $\mathrm{PM}_{2.5} \mathrm{EC}$ accounted for $75.0 \%$ and $59.6 \%$ of $\mathrm{PM}_{10} \mathrm{EC}$ in fall and winter (Table 1). Less than $60 \%$ of $\mathrm{PM}_{10} \mathrm{EC}$ resided in $\mathrm{PM}_{2.5}$ in winter, possibly due to coarse soot particles in the emissions of incomplete coal combustion, or from fugitive coal dust.

\subsection{The characterization of eight carbon fractions}

The IMPROVE_TOR protocol does not advance from one temperature to the next until a well-defined carbon peak has evolved (Chow et al., 1993, 2004a). Carbon abundances in each of these fractions differ by carbon source (Chow et al., 2004b; Watson et al., 1994). Eight carbon fractions have 
Table 2. Statistical summary of the percentage of OC, EC, and TCA\% in $\mathrm{PM}_{2.5}$ and $\mathrm{PM}_{10}^{\mathrm{a}}$.

\begin{tabular}{ccccccccccc}
\hline \multirow{2}{*}{ Season } & Month & $\begin{array}{c}\mathrm{TCA}(\%) \\
\mathrm{PM}_{2.5}\end{array}$ & $\mathrm{PM}_{10}$ & $\mathrm{PM}_{2.5} / \mathrm{PM}_{10}$ & $\begin{array}{c}\mathrm{OC}(\%) \\
\mathrm{PM}_{2.5}\end{array}$ & $\mathrm{PM}_{10}$ & $\mathrm{PM}_{2.5} / \mathrm{PM}_{10}$ & $\begin{array}{c}\mathrm{EC}(\%) \\
\mathrm{PM}_{2.5}\end{array}$ & $\mathrm{PM}_{10}$ & $\mathrm{PM}_{2.5} / \mathrm{PM}_{10}$ \\
\hline \multirow{6}{*}{ Fall } & September & $45.0 \pm 7.6$ & $26.4 \pm 1.5$ & $83.0 \pm 6.4$ & $23.5 \pm 4.3$ & $13.6 \pm 1.0$ & $84.9 \pm 5.8$ & $7.3 \pm 1.6$ & $4.7 \pm 0.8$ & $74.8 \pm 13.4$ \\
& October & $51.0 \pm 10.7$ & $38.8 \pm 8.8$ & $79.4 \pm 6.2$ & $26.6 \pm 5.5$ & $20.4 \pm 4.8$ & $80.2 \pm 6.1$ & $8.4 \pm 2.7$ & $6.3 \pm 1.6$ & $75.0 \pm 10.1$ \\
& Average & $48.8 \pm 10.1$ & $34.5 \pm 9.3$ & $80.7 \pm 6.3$ & $25.5 \pm 5.3$ & $18.0 \pm 5.1$ & $81.8 \pm 6.3$ & $8.0 \pm 2.4$ & $5.7 \pm 1.6$ & $75.0 \pm 11.0$ \\
& & & & & & & & & & \\
\multirow{6}{*}{ Winter } & November & $44.8 \pm 7.4$ & $35.7 \pm 4.6$ & $69.8 \pm 11.8$ & $24.3 \pm 3.9$ & $18.9 \pm 2.5$ & $71.8 \pm 12.2$ & $5.9 \pm 1.7$ & $5.4 \pm 0.9$ & $58.7 \pm 12.0$ \\
& December & $50.3 \pm 5.5$ & $42.4 \pm 7.7$ & $65.9 \pm 13.3$ & $27.9 \pm 2.8$ & $23.0 \pm 4.5$ & $67.6 \pm 14.0$ & $5.6 \pm 1.5$ & $5.6 \pm 1.3$ & $55.2 \pm 10.6$ \\
& January & $44.0 \pm 8.1$ & $37.0 \pm 11.7$ & $75.0 \pm 9.1$ & $24.9 \pm 4.6$ & $20.6 \pm 7.1$ & $77.0 \pm 9.6$ & $4.0 \pm 1.1$ & $4.1 \pm 0.8$ & $61.4 \pm 7.3$ \\
& February & $44.8 \pm 7.5$ & $32.4 \pm 7.4$ & $72.2 \pm 11.9$ & $24.2 \pm 4.4$ & $17.2 \pm 4.3$ & $74.0 \pm 13.1$ & $6.1 \pm 1.4$ & $4.9 \pm 0.8$ & $63.2 \pm 9.4$ \\
& Average & $45.9 \pm 7.5$ & $37.0 \pm 8.9$ & $71.0 \pm 11.5$ & $25.4 \pm 4.2$ & $20.0 \pm 5.3$ & $72.8 \pm 12.1$ & $5.4 \pm 1.6$ & $5.0 \pm 1.1$ & $59.6 \pm 9.8$ \\
\hline
\end{tabular}

${ }^{\text {a }}$ values represent average \pm standard deviation

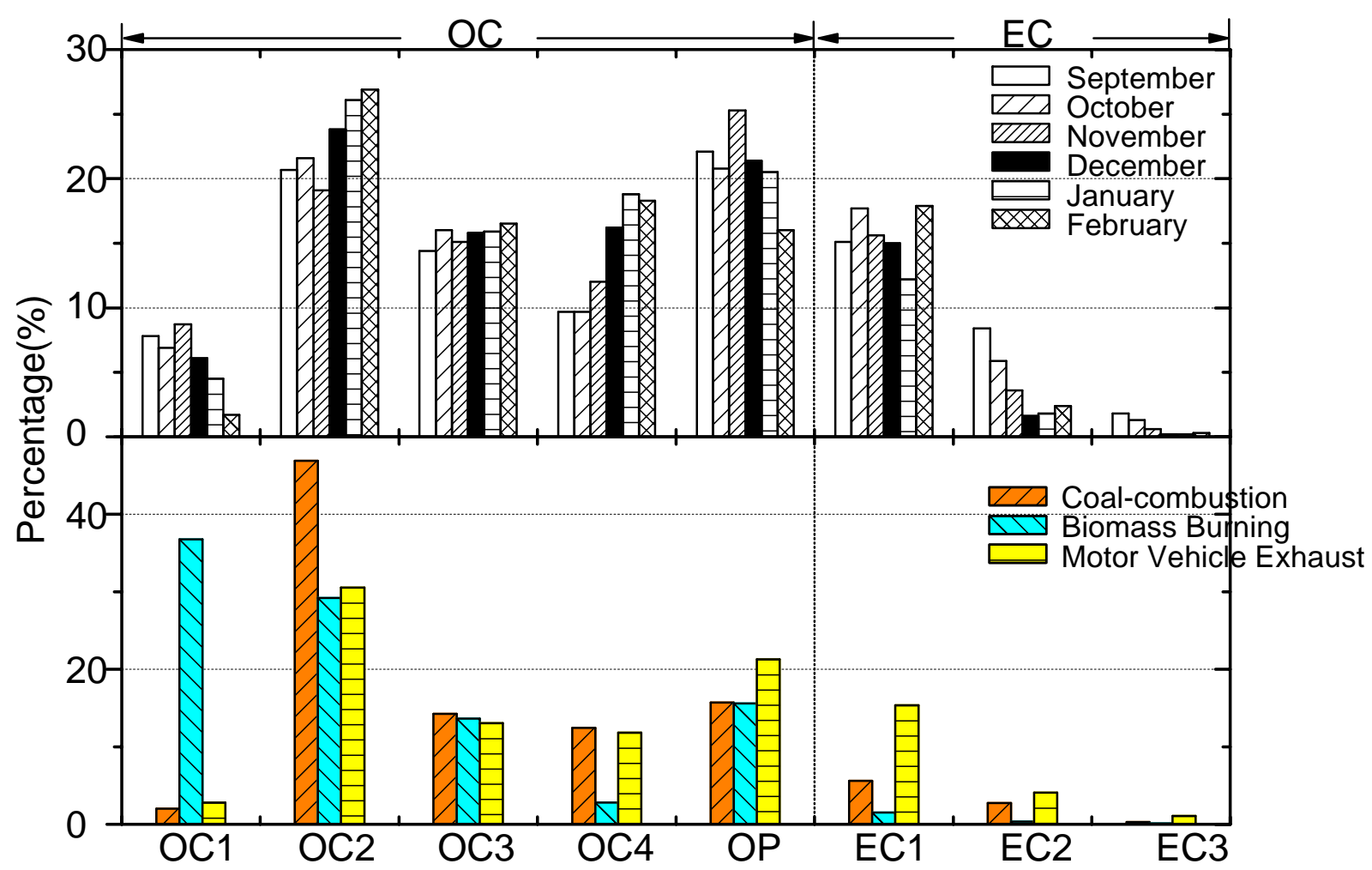

Fig. 5. Abundances (mass fraction of total carbon) of eight thermally-derived carbon fractions in ambient and source samples.

been used before for the source apportionment of carbonaceous aerosol (Kim et al., 2003a, b; Kim and Hopke, 2004).

The average percentages of eight carbon fractions in ambient and source samples are shown in Fig. 5. Distinct differences in carbon fractions are evident among samples from the three source types tested in this study. OC1 contributed $36.8 \%$ to TC in biomass-burning samples, $2.0 \%$ in coal-combustion samples, and $2.8 \%$ in motor-vehicle exhaust samples. OC2 accounted for $46.9 \%$ of TC in coalcombustion samples, $29.2 \%$ in biomass-burning samples and $30.5 \%$ in motor-vehicle samples. EC1 constituted $15.4 \%$ to
TC, $5.6 \%$ in coal-combustion samples and $0.4 \%$ in biomassburning samples.

Monthly variations of the eight carbon fractions were related to the contributions of different emission sources. November experienced the highest contribution from biomass burning, with OC1 attaining $8.7 \%$, which was the highest value in the six months of the study. OC1 decreased to $1.7 \%$ in February. OC2 increased during the six months (except for November), possibly reflecting the increased contributions of coal combustion from fall to winter. EC1 reached its lowest values in January, possibly caused by 
Table 3. Comparison of $\mathrm{PM}_{2.5} \mathrm{OC}, \mathrm{EC}$ at $\mathrm{Xi}$ ' an with other Asian cities.

\begin{tabular}{|c|c|c|c|c|c|c|c|}
\hline City & Period & $\mathrm{TC}$ & $\begin{array}{l}\mathrm{OC} \\
\left(\mu \mathrm{g} \mathrm{m}^{-3}\right)\end{array}$ & $\mathrm{EC}$ & $\mathrm{OC} / \mathrm{EC}$ & $\begin{array}{l}\text { Measurement } \\
\text { method }\end{array}$ & Reference \\
\hline \multirow{2}{*}{ Xi'an } & Fall, 2003 & 45.4 & $34.1 \pm 18.0$ & $11.3 \pm 6.9$ & 3.3 & IMPROVE_TOR & This study \\
\hline & Winter 2003 & 74.2 & $61.9 \pm 33.2$ & $12.3 \pm 5.3$ & 5.1 & IMPROVE_TOR & This study \\
\hline \multirow{2}{*}{ Beijing $^{1}$} & Fall 1999 & 39.0 & 28.8 & 10.2 & 2.8 & IMPROVE_TOR & \multirow{2}{*}{ He et al. (2001) } \\
\hline & Winter 1999 & 42.6 & 31.5 & 11.1 & 2.8 & IMPROVE_TOR & \\
\hline Beijing ${ }^{2}$ & December 2002 & 51.9 & $36.7 \pm 19.4$ & $15.2 \pm 11.1$ & 3.5 & Elemental analyzer & Dan et al. (2004) \\
\hline Beijing $^{3}$ & November 1997-October 1998 & & $41.5^{4}$ & No data & & Elemental analyzer & Duan et al. (2004) \\
\hline \multirow{2}{*}{ Shanghai ${ }^{5}$} & Fall 1999 & 23.2 & 16.3 & 6.9 & 2.4 & IMPROVE_TOR & \multirow{2}{*}{ Ye et al. (2003) } \\
\hline & Winter, 1999 & 25.1 & 17.0 & 8.1 & 2.1 & IMPROVE_TOR & \\
\hline Hong Kong & January-February 2002 & 14.4 & $9.6 \pm 4.5$ & $4.7 \pm 2.9$ & 2.3 & IMPROVE_TOR & Cao et al. (2003) \\
\hline Guangzhou & January-February 2002 & 31.0 & $22.6 \pm 18.0$ & $8.3 \pm 5.6$ & 2.7 & IMPROVE_TOR & Cao et al. (2003) \\
\hline Shenzhen & January-February 2002 & 19.2 & $13.2 \pm 4.1$ & $6.1 \pm 1.8$ & 2.2 & IMPROVE_TOR & Cao et al. (2003) \\
\hline Zhuhai & January-February 2002 & 17.3 & $12.2 \pm 4.4$ & $5.0 \pm 1.6$ & 2.4 & IMPROVE_TOR & Cao et al. (2003) \\
\hline Kaohsiung & November 1998-April 1999 & 14.5 & 10.4 & 4.0 & 2.6 & Elemental analyzer & (Lin \& Tai, 2001) \\
\hline \multirow{2}{*}{ Chongju, Korea } & Fall, 1995 & 12.4 & 6.0 & 6.4 & 0.9 & IMPROVE_TOR & \multirow{2}{*}{ Lee and Kang (2001) } \\
\hline & Winter 1995 & 9.3 & 5.0 & 4.3 & 1.2 & IMPROVE_TOR & \\
\hline \multirow{2}{*}{ Sapporo, Japan } & September-October 1992 & 9.1 & 4.1 & 5.0 & 0.8 & Elemental analyzer & \multirow{2}{*}{ Ohta et al. (1998) } \\
\hline & January-February 1992 & 9.0 & 3.9 & 5.1 & 0.8 & Elemental analyzer & \\
\hline \multirow{2}{*}{ Uji, Japan } & September-October 1998 & 6.4 & 1.8 & 4.6 & 0.4 & R\&P 5400 & \multirow{2}{*}{ Holler et al. (2002) } \\
\hline & November-December 1998 & 10.2 & 2.5 & 7.7 & 0.3 & R\&P 5400 & \\
\hline
\end{tabular}

${ }^{1}$ Chegongzhuang site.

2 Average of 3 sites: Beijing Normal University, Capital Steel Plant, Yihai Garden.

3 Temple of Heaven.

${ }^{4}$ Annual average.

5 Average of Tongji University and Hainan Road.

lower motor vehicle activity during the Chinese Spring Festival. OP ranged from $16.0 \%$ to $22.1 \%$, with an average of $21.0 \%$. These ratios are higher than the 8.0 to $17.8 \%$ OP in TC found during summer for the Pearl River Delta Region in China (Cao et al., 2004).

\subsection{Periodic characteristics of OC and EC}

The periodic features of emission sources and meteorological conditions can be identified from the OC/EC time series. Hies (2000) showed that domestic heating by coal combustion appears with a 365-day periodicity. In this study, traffic in Berlin, Germany contributes 3.5-, 4.6-, and 7-day peaks in the spectrum, and periodicity for elevated EC can be identified in the 13- to 42-day range.
The comparison of periodicities of $\mathrm{OC}, \mathrm{EC}, \mathrm{PM}_{2.5}$ mass, and daily average wind speed are illustrated in Fig. 6. These curves were obtained by AutoSignal 1.0 software (SPSS, USA). The common periodicities of OC, $\mathrm{EC}$ and $\mathrm{PM}_{2.5}$ were $24,10,7$, and 5 days. Identical periodicities between $\mathrm{PM}_{2.5}$ mass and $\mathrm{OC}$ are consistent as they are controlled by similar processes. In agreement with Hies (2000), the periodicities of motor vehicle variations were five and seven days. Precipitation events had 10-day periodicity from September to November. This periodicity should reflect the impact of precipitation on OC and EC concentrations. Thirteen-day periodicity was a major component in the wind speed spectrum identified by Hies (2000), which also influences EC concentrations. Sixty-day peaks may be related to the change of primary emission sources. 

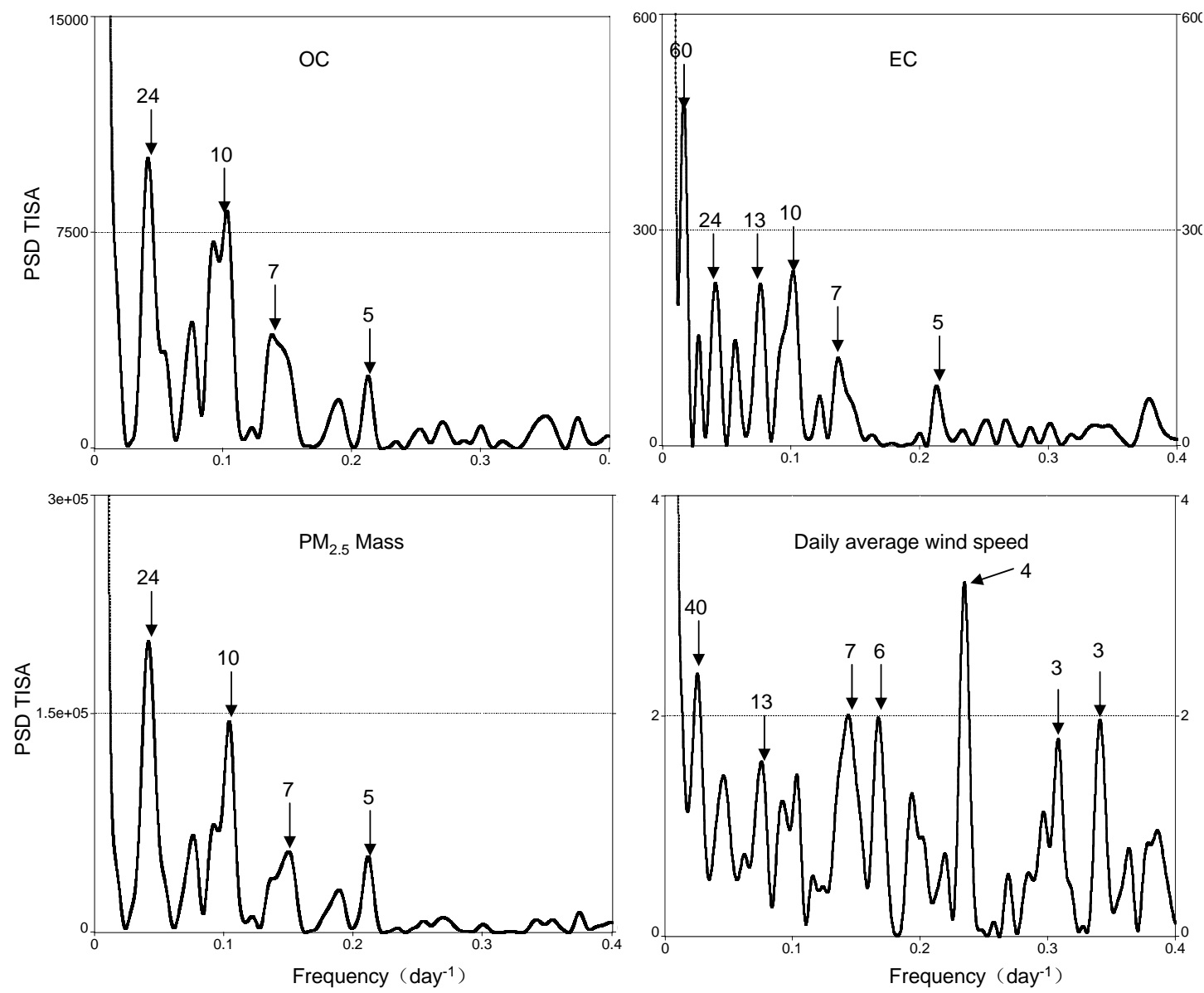

Fig. 6. Periodicity of $\mathrm{PM}_{2.5}$ OC, EC, mass, and daily average wind speed. (PSD TISA on the Y axis refers to Power as Time-Integral Squared Amplitude.)

\subsection{Comparison of OC and EC with other Asian cities}

Table 3 compares TC, OC, and EC concentrations in $\mathrm{PM}_{2.5}$ from 11 Asian cities. Total carbon in fall and winter at Xi' an ranked the highest. While $\mathrm{OC}$ and $\mathrm{EC}$ concentrations were similar in Beijing and Xi' an in fall, OC in Xi' an was twice that of Beijing in winter, with similar EC levels. This may be due to more motor vehicles and less coal use in Beijing (Yang et al., 2005). Winter OC levels in Xi' an were 2.7, 3.6, 4.7, 5.1, and 6.4 times those in Guangzhou, Shanghai, Shenzhen, Zhuhai, and Hong Kong, respectively (the number of motor vehicles in these coastal cities are 1.1, 0.7, 0.7, 0.3, and 0.5 million, respectively, compared with 0.2 million in Xi'an). Winter EC levels in Xi' an were 1.5, 1.5, 2.0, 2.5, and 2.6 times those of these coastal cities. The lower increment for EC may be attributed to the high emissions of motor-vehicle exhaust in the coastal cities, and the larger increment for OC may be ascribed to the lower use of coal for residential heating (there is almost no use of coal for residential heating in the coastal cities). Winter OC and EC levels in Xi' an were 12.4 and 2.9 times, respectively, those in Chongju, South Korea (Lee and Kang, 2001).

\subsection{Source apportionment of carbonaceous PM}

Absolute principal component analysis (APCA) (Thurston and Spengler, 1985) was applied to the eight carbon fraction concentrations to identify and quantify source contributions. The first step in APCA is the normalization of all carbon concentrations as $Z_{i k}$. This is done by adding a zero concentration sample as case 0 (The $Z_{i 0}$ is obtained by deriving the $Z$-score for absolute zero concentrations).

$Z_{i k}=\left(C_{i k}-C_{i}\right) / S_{i}$

where $C_{i k}$ is the concentration of carbon fraction $i$ in sample $k, C_{i}$ is the arithmetic mean concentration of carbon fraction $i$, and $S_{i}$ is the standard deviation of carbon fraction $i$ for all samples included in the analysis. The normalization process allows any continuous variable, such as wind speed, to be included in future analyses along with the carbon data.

Regressing the TC data on these absolute principal component scores (APCS) gives estimates of the coefficients which convert the APCS into TC contributions from each source for each sample. For each source identified by the APCA, 
Table 4. APCA results of fall samples.

\begin{tabular}{cccc}
\hline & F1 & F2 & F3 \\
\hline OC1 & 0.32 & 0.12 & $\underline{0.91}$ \\
OC2 & $\underline{0.96}$ & 0.16 & 0.17 \\
OC3 & $\underline{0.89}$ & 0.11 & 0.38 \\
OC4 & $\underline{0.95}$ & 0.19 & 0.19 \\
OP & $\underline{0.88}$ & 0.25 & 0.13 \\
EC1 & $\underline{0.88}$ & 0.21 & 0.39 \\
EC2 & 0.62 & $\underline{0.65}$ & -0.28 \\
EC3 & 0.12 & $\underline{0.94}$ & 0.23 \\
Variance & $68 \%$ & $14 \%$ & $10 \%$ \\
Eigen value & 5.60 & 1.10 & 0.80 \\
& Gasoline & Diesel & Biomass \\
& Exhaust & Exhaust & Burning \\
\hline
\end{tabular}

the weighted regression of each carbon fraction's concentration on the predicted TC contributions yields estimates of the content of that fraction in each source, as follows:

$C_{i k}=b+\sum_{j=1}^{n} a_{i j} M_{j k}$

where $C_{i k}$ is the concentration of carbon fraction $i$ in sample $k ; b$ is a constant; $a_{i j}$ is the mean TC fraction of source $j$ 's particles represented by carbon fraction $i$, and $M_{j k}$ is the TC concentration of source $j$ for observation $k$. By repeating this weighted least-square regression for each of the $i=1$, $2, \ldots \mathrm{n}$ carbon fractions considered in this analysis, one can estimate the mean concentration of the carbon fractions for each factor.

Results for fall and winter are summarized in Tables 4 and 5. Factor 1 (F1) in fall was highly loaded with OC2, OC3, $\mathrm{OC} 4, \mathrm{OP}$, and EC1. This factor appears to represent gasolinemotor-vehicle exhaust (Chow et al., 2004b). Factor 2 (F2) was highly loaded with high-temperature EC2 and EC3 and appears to represent diesel-vehicle exhaust (Watson et al., 1994). The high loading of OC1 in factor 3 (F3) reflects the contribution of biomass burning. In winter, the highly loaded OC2, OC3, OC4, and EC1 in F1 might represent the mixture of coal-combustion and motor-vehicle exhaust. Similar to the fall results, F2 and F3 in winter represent biomass burning and diesel-vehicle exhaust, respectively.

To simplify the estimation, it is assumed that there is no contribution of coal combustion in fall, and there are equal contributions from gasoline-powered motor vehicles in fall and winter. Coal combustion in winter is assumed to be the difference between winter F1 and fall F1, thus the source attributions can be resolved for the two seasons (Fig. 7). During fall, TC is composed of $73 \%$ from gasoline exhaust, $23 \%$ from diesel exhaust, and $4 \%$ from biomass burning. During winter, TC receives $44 \%$ from gasoline exhaust, $3 \%$ from
Table 5. APCA results of winter samples.

\begin{tabular}{cccc}
\hline & F1 & F2 & F3 \\
\hline OC1 & 0.09 & $\underline{0.98}$ & 0.06 \\
OC2 & $\underline{0.97}$ & 0.03 & 0.05 \\
OC3 & $\underline{\underline{0.87}}$ & 0.44 & 0.07 \\
OC4 & $\underline{0.96}$ & 0.05 & -0.01 \\
OP & 0.60 & $\underline{0.67}$ & 0.24 \\
EC1 & $\underline{0.73}$ & 0.50 & 0.17 \\
EC2 & -0.05 & 0.12 & $\underline{0.90}$ \\
EC3 & 0.17 & 0.06 & $\underline{0.88}$ \\
Variance & $55 \%$ & $21 \%$ & $13 \%$ \\
Eigen value & 4.40 & 1.60 & 1.10 \\
& Coal Combustion + & Biomass & Diesel \\
& Gasoline Exhaust & Burning & Exhaust \\
\hline
\end{tabular}

Fall: $\mathrm{TC}=45.1 \mu \mathrm{g} \mathrm{m}^{-3} \quad 4 \%$

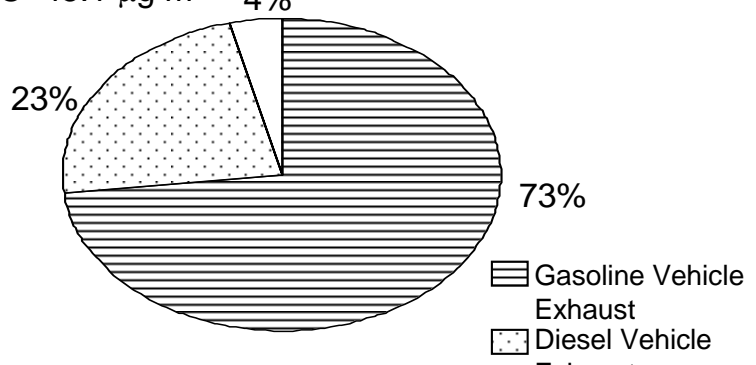

Winter: $\mathrm{TC}=74.2 \mu \mathrm{g} \mathrm{m}^{-3}$

Exhaust

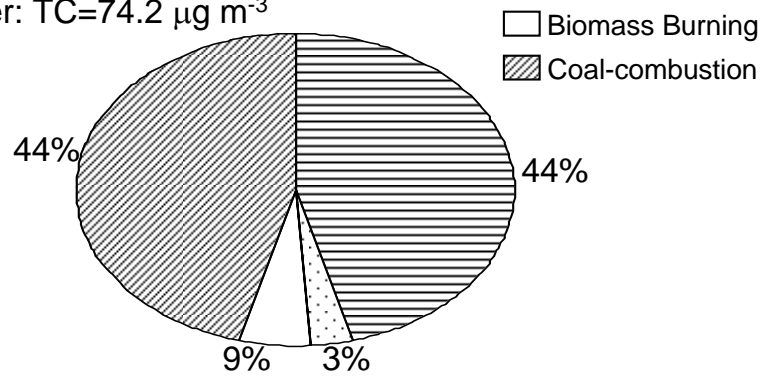

Fig. 7. Relative contributions of major sources to $\mathrm{PM}_{2.5}$ TC during fall and winter 2003 .

diesel exhaust, $9 \%$ from biomass burning, and $44 \%$ from coal burning.

\section{Conclusions}

Six months of continuous observations were conducted at Xi' an, Shaanxi Province, China to gain insight into the characterization and source apportionment of organic and elemental carbon (OC/EC). Major findings are as follows.

1. Average $\mathrm{PM}_{2.5} \mathrm{OC}$ concentrations during fall and winter were $34.1 \pm 18.0 \mu \mathrm{g} \mathrm{m}^{-3}$ and $61.9 \pm 33.2 \mu \mathrm{g} \mathrm{m}^{-3}$; EC concentrations were $11.3 \pm 6.9 \mu \mathrm{g} \mathrm{m}^{-3}$ and 
$12.3 \pm 5.3 \mu \mathrm{g} \mathrm{m}^{-3}$, respectively. Carbonaceous aerosol accounted for $48.8 \pm 10.1 \%$ and $45.9 \pm 7.5 \%$ of $\mathrm{PM}_{2.5}$ and $34.5 \pm 9.3 \%$ and $37 \pm 8.9 \%$ of $\mathrm{PM}_{10}$ during fall and winter, respectively. This indicates that carbonaceous aerosol is the dominant component of fine particles in Xi'an.

2. All of the OC/EC ratios exceeded 2.0, and average $\mathrm{OC} / \mathrm{EC}$ ratios were 3.3 in fall and 5.1 in winter. Elevated $\mathrm{OC} / \mathrm{EC}$ ratios were found during heating seasons with increased primary emissions, such as residential coal combustion. $\mathrm{PM}_{2.5}$ OC and $\mathrm{PM}_{10}$ OC were highly correlated $(\mathrm{R}=0.95-0.97)$ during fall, and moderately correlated $(\mathrm{R}=0.81)$ during winter.

3. $\mathrm{PM}_{2.5}$ total carbon source apportionment by APCA attributed $73 \%$ to gasoline engine exhaust, $23 \%$ to diesel engine exhaust, and $4 \%$ to biomass burning during fall, and $44 \%$ to gasoline engine exhaust, $44 \%$ to residential coal burning, $9 \%$ to biomass burning, and $3 \%$ to diesel engine exhaust during winter. Motor-vehicle exhaust and coal combustion were the dominant sources for carbonaceous aerosol in Xi'an.

Acknowledgements. This project was supported by the National Basic Research Program of China (2004CB720203), National Natural Science Foundation of China (40121303, 40205018), and Research Grants Council of Hong Kong (PolyU5038/01E, PolyU5145/03E), Area of Strategic Development on Atmospheric and Urban Air Pollution (A516) funded by The Hong Kong Polytechnic University. T. Richard edited the manuscript and J. Gerard assisted in formatting and corrections.

Edited by: R. Hitzenberger

\section{References}

ACE-Asia: Asian Pacific Regional Aerosol Characterization Experiment, http://saga.pmel.noaa.gov/aceasia/, 1999.

Cachier, H., Bremond, M. P., and Buat-Menard, P.: Carbonaceous aerosols from different tropical biomass burning sources, Nature, 340, 371-373, 1989.

Cachier, H., Liousse, C., Pertuisol, M. H., Gaudichet, A., Echalar, F., and Lacaux, J. P.: African fine particulate emissions and atmospheric influence, in: Biomass Burning and Global Change, edited by: Levine, E. J. S., MIT Press, London, 428-440, 1996.

Cao, J. J., Lee, S. C., Ho, K. F., Zhang, X. Y., Zou, S. C., Fung, K. K., Chow, J. C., and Watson, J. G.: Characteristics of carbonaceous aerosol in Pearl River Delta region, China during 2001 winter period, Atmos. Environ., 37(11), 1451-1460, 2003.

Cao, J. J., Lee, S. C., Ho, K. F., Zou, S. C., Fung, K. K., Li, Y., Watson, J. G., and Chow, J. C.: Spatial and seasonal variations of atmospheric organic carbon and elemental carbon in Pearl River Delta Region, China, Atmos. Environ., 38, 4447-4456, 2004.

Cao, J. J., Lee, S. C., Zhang, X. Y., Chow, J. C., An, Z. S., Ho, K. F., Watson, J. G., Fung, K. K., Wang, Y. Q., and Shen, Z. X.: Characterization of airborne carbonate over a site near Asian dust source regions during spring 2002 and its climatic and environmental significance, J. Geophys. Res., 110(D03203), 1-8, doi:10.1029/2004JD005244, 2005.

Chow, J. C., Engelbrecht, J. P., Watson, J. G., Wilson, W. E., Frank, N. H., and Zhu, T.: Designing monitoring networks to represent outdoor human exposure, Chemosphere, 49(9), 961-978, 2002.

Chow, J. C., Watson, J. G., Crow, D., Lowenthal, D. H., and Merrifield, T. M.: Comparison of IMPROVE and NIOSH carbon measurements, Aerosol Science \& Technology, 34(1), 23-34, 2001.

Chow, J. C., Watson, J. G., Chen, L.-W. A., Arnott, W. P., Moosmüller, H., and Fung, K. K.: Equivalence of elemental carbon by Thermal/Optical Reflectance and Transmittance with different temperature protocols, Environmental Science \& Technology, 38(16), 4414-4422, 2004a.

Chow, J. C., Watson, J. G., Kuhns, H. D., Etyemezian, V., Lowenthal, D. H., Crow, D. J., Kohl, S. D., Engelbrecht, J. P., and Green, M. C.: Source profiles for industrial, mobile, and area sources in the Big Bend Regional Aerosol Visibility and Observational (BRAVO) Study, Chemosphere, 54(2), 185-208, 2004b.

Chow, J. C., Watson, J. G., Louie, P. K. K., Chen, L.-W. A., and Sin, D.: Comparison of PM2.5 carbon measurement methods in Hong Kong, China, Environmental Pollution, 137(2), 334-344, 2005.

Chow, J. C., Watson, J. G., Lu, Z., Lowenthal, D. H., Frazier, C. A., Solomon, P. A., Thuillier, R. H., and Magliano, K. L.: Descriptive analysis of $\mathrm{PM}_{2.5}$ and $\mathrm{PM}_{10}$ at regionally representative locations during SJVAQS/AUSPEX, Atmos. Environ., 30(12), 2079-2112, 1996.

Chow, J. C., Watson, J. G., Pritchett, L. C., Pierson, W. R., Frazier, C. A., and Purcell, R. G.: The DRI Thermal/Optical Reflectance carbon analysis system: Description, evaluation and applications in U.S. air quality studies, Atmos. Environ., 27A(8), 1185-1201, 1993.

Cooke, W. F., Liousse, C., Cachier, H., and Feichter, J.: Construction of a 1 degrees $\times 1$ degrees fossil fuel emission data set for carbonaceous aerosol and implementation and radiative impact in the ECHAM4 model, J. Geophys. Res., 104(D18), 22 137$22162,1999$.

Dan, M., Zhuang, G. S., Li, X. X., Tao, H. R., and Zhuang, Y. H.: The characteristics of carbonaceous species and their sources in PM2.5 in Beijing, Atmos. Environ., 38(21), 3443-3452, 2004.

Duan, F. K., Liu, X. D., Yu, T., and Cachier, H.: Identification and estimate of biomass burning contribution to the urban aerosol organic carbon concentrations in Beijing, Atmos. Environ., 38(9), 1275-1282, 2004.

Fung, K. K., Chow, J. C., and Watson, J. G.: Evaluation of OC/EC speciation by thermal manganese dioxide oxidation and the IMPROVE method, J. Air \& Waste Management Association, 52(11), 1333-1341, 2002.

Gao, Y., Arimoto, R., Duce, R. A., Zhang, X. Y., Zhang, G. Y., An, Z. S., Chen, L. Q., Zhou, M. Y., and Gu, D. Y.: Temporal and spatial distributions of dust and its deposition to the China Sea, Tellus, 49B(2), 172-189, 1997.

Gray, H. A., Cass, G. R., Huntzicker, J. J., Heyerdahl, E. K., and Rau, J. A.: Characteristics of atmospheric organic and elemental carbon particle concentrations in Los Angeles, Environ. Sci. Technol., 20(6), 580-589, 1986.

He, K., Yang, F., Ma, Y., Zhang, Q., Yao, X., Chan, C. K., Cadle, S., Chan, T., and Mulawa, P.: The characteristics of $\mathrm{PM}_{2.5}$ in 
Beijing, China, Atmos. Environ., 35(29), 4959-4970, 2001.

Hies, T., Treffeisen, R., Sebald, L., and Reimer, E.: Spectral analysis of air pollutants Part 1. Elemental carbon time series, Atmos. Environ., 34(21), 3495-3502, 2000.

Holler, R., Tohnoa, S., Kasaharaa, M., et al.: Long-term characterization of carbonaceous aerosol in Uji, Japan, Atmos. Environ., 36, 1267-1275, 2002.

IPCC: Climate Change 2001: The Scientific Basis, Cambridge University Press, Cambridge, 2001.

Jacobson, M. Z.: Control of fossil-fuel particulate black carbon plus organic matter, possibly the most effective method of slowing global warming, J. Geophys. Res., 107(D19), ACH 16-1-ACH 16-22, 2002.

Kim, E. and Hopke, P. K.: Improving source identification of fine particles in a rural northeastern US area utilizing temperatureresolved carbon fractions, J. Geophys. Res., 109(D09204), 1-13, doi:10.1029/2003JD004199, 2004.

Kim, E., Hopke, P. K., and Edgerton, E. S.: Source identification of Atlanta aerosol by positive matrix factorization, J. Air \& Waste Management Association, 53(6), 731-739, 2003a.

Kim, E., Larson, T. V., Hopke, P. K., Slaughter, C., Sheppard, L. E., and Claiborn, C.: Source identification of PM2.5 in an arid northwest U.S. city by positive matrix factorization, Atmos. Res., 66, 291-305, 2003b.

Lee, H. S. and Kang, B. W.: Chemical characteristics of principal $\mathrm{PM}_{2.5}$ species in Chongju, South Korea, Atmos. Environ., 35(4), 739-746, 2001.

Li, Y.: Characterization and source apportionment of atmospheric organic and elemental carbon in Xi'an, China, Master Thesis, Institute of Earth Environment, Chinese Academy of Sciences, Lanzhou, China, 2004.

Lin, J. J. and Tai, H. S.: Concentrations and distributions of carbonaceous species in ambient particles in Kaohsiung City, Taiwan, Atmos. Environ., 35(15), 2627-2636, 2001.

Louie, P. K. K., Chow, J. C., Chen, L.-W. A., Watson, J. G., Leung, G., and Sin, D.: PM2.5 chemical composition in Hong Kong: Urban and regional variations, Science of the Total Environment, 338(3), 267-281, 2005a.

Louie, P. K. K., Watson, J. G., Chow, J. C., Chen, L.-W. A., Sin, D. W. M., and Lau, A. K. H.: Seasonal characteristics and regional transport of PM2.5 in Hong Kong, Atmos. Environ., 39(9), 1695-1710, 2005b.

Menon, S., Hansen, J. E., Nazarenko, L., and Luo, Y.: Climate effects of black carbon aerosols in China and India, Science, 297(5590), 2250-2252, 2002.

Ohta, S., Hori, M., Yamagata, S., and Murao, N.: Chemical characterization of atmospheric fine particles in Sapporo with determination of water content, Atmos. Environ., 32(6), 1021-1026, 1998.

Streets, D. G., Gupta, S., Waldhoff, S. T., Wang, M. Q., Bond, T. C., and Yiyun, B.: Black carbon emissions in China, Atmos. Environ., 35(25), 4281-4296, 2001.

Thurston, G. D. and Spengler, J. D.: A quantitative assessment of source contributions to inhalable particulate matter pollution in metropolitan Boston, Atmos. Environ., 19(1), 9-25, 1985.
Turpin, B. J. and Huntzicker, J. J.: Secondary formation of organic aerosol in the Los Angeles Basin: A descriptive analysis of organic and elemental carbon concentrations, Atmos. Environ., 25A(2), 207-215, 1991.

Turpin, B. J. and Lim, H. J.: Species contributions to $\mathrm{PM}_{2.5}$ mass concentrations: Revisiting common assumptions for estimating organic mass, Aerosol Sci. Technol., 35(1), 602-610, 2001.

UNEP and NOAA: Project Atmospheric Brown Clouds (ABC), http://www-abc-asia.ucsd.edu/, 2002.

Vedal, S.: Critical review - Ambient particles and health: Lines that divide, J. Air \& Waste Management Association, 47(5), 551$581,1997$.

Watson, J. G.: Visibility: Science and regulation, J. Air \& Waste Management Association, 52(6), 628-713, 2002.

Watson, J. G., Chow, J. C., and Chen, L.-W. A.: Summary of organic and elemental carbon/black carbon analysis methods and intercomparisons, Aerosol and Air Quality Research, 5(1), 69$102,2005$.

Watson, J. G., Chow, J. C., and Houck, J. E.: PM 2.5 chemical source profiles for vehicle exhaust, vegetative burning, geological material, and coal burning in northwestern Colorado during 1995, Chemosphere, 43(8), 1141-1151, 2001.

Watson, J. G., Chow, J. C., Lowenthal, D. H., Pritchett, L. C., Frazier, C. A., Neuroth, G. R., and Robbins, R.: Differences in the carbon composition of source profiles for diesel- and gasolinepowered vehicles, Atmos. Environ., 28(15), 2493-2505, 1994.

Wei, F., Teng, E., Wu, G., Hu, W., Wilson, W. E., Chapman, R. S., Pau, J. C., and Zhang, J.: Ambient concentrations and elemental compositions of $\mathrm{PM}_{10}$ and $\mathrm{PM}_{2.5}$ in four Chinese cities, Environ. Sci. Technol., 33(23), 4188-4193, 1999.

Yang, F., He, K., Ye, B., Chen, X., Cha, L., Cadle, S. H., Chan, T., and Mulawa, P. A.: One-year record of organic and elemental carbon in fine particles in downtown Beijing and Shanghai, Atmos. Chem. Phys., 5, 1449-1457, 2005,

SRef-ID: 1680-7324/acp/2005-5-1449.

Ye, B., Ji, X., Yang, H., Yao, X., Chan, C. K., Cadle, S. H., Chan, T., and Mulawa, P. A.: Concentration and chemical composition of $\mathrm{PM}_{2.5}$ in Shanghai for a 1-year period, Atmos. Environ., 37(4), 499-510, 2003.

Zhang, X. Y., Arimoto, R., An, Z. S., Chen, T., Zhang, G., Zhu, G., and Wang, X.: Atmospheric trace elements over source regions for Chinese dust: Concentrations, sources, and atmospheric deposition on the Loess Plateau, Atmos. Environ., 27A(13), 20512067, 1993.

Zhang, X. Y., Cao, J. J., Li, L. M., Arimoto, R., Cheng, Y., Huebert, B., and Wang, D.: Characterization of atmospheric aerosol over Xian in the south margin of the Loess Plateau, China, Atmos. Environ., 36(26), 4189-4199, 2002.

Zhang, X. Y., Cao, J. J., Su, H., et al.: Particulate pollution control in Xi'an, in: Urban Air Pollution Control in China, edited by: United Nations Development Program and China International Center of Economic and Technology Exchange, China Science \& Technology Press, 222-293, 2001.

Zhuang, G. S., Zhen, Y., Duce, R. A., and Brown, P. R.: Link between iron an sulphur cycles suggested by detection of $\mathrm{Fe}$ (II) in remote marine aerosols, Nature, 355(6360), 537-539, 1992. 